\title{
LA POESIA DE GABRIELA MISTRAL: "TALA" $\left({ }^{1}\right)$
}

\author{
Eduardo Peñula Cañizal \\ Professor universitário
}

Los poemas que Gabriela Mistral dedica a la muerte de su madre no se limitan exclusivamente al estado afectivo de la poetisa provocado por la ausencia del ser querido, no nos emocionan sólo por lo que este estado tiene de rasgado dolor, sino también por su contenido desbordado, hondamente humano, que sobrepasa las circunstancias de lo individual.

La muerte ha sido un tema constante en la poesía de Gabriela desde su primer libro; ha sido un motivo de dolorida comunicación, galeria abierta hacia el mensaje transcendental. El vacío de la ausencia definitiva, grande e intransferible, se ha bifurcado poéticamente para realizarse de manera universal, sin perder nunca su presencia individual. Esta dualidad del mensaje ha enriquecido toda la obra de la poetisa chilena, quien con su intuición femenina ha conseguido amplio halo de simpatías, una repercusión derramada.

Este pequeño ensayo o intento crítico, mostrará en algunas ocasiones esa dualidad comunicativa, aunque no sea éste nuestro propósito. Vamos a analizar rápidamente la belleza de determinados recursos poéticos y, al mismo tiempo, apuntaremos elementos femeninos en la forma y en el fondo de estos poemas. No nos detendremos en los valores simbólicos de estos versos, campo más delicado y sujeto a engaños y confusiones; y dejaremos de lado, para otra oportunidad, el estudio de las comparaciones, recursos expresivos que alcanzan originalidad conservando rasgos $\operatorname{arcaicos}^{(2)}$.

\footnotetext{
(1) - Nos hemos ocupado solamente de los poemas dedicados a la muerte de su madre. La edición que hemos utilizado: MISTRAL, Gabriela:- "TALA" Editorlal Losada S.A. - Buenos Alres - 1957 - 3.* ediclón.

(2) - Nos referimos a las comparaciones cuyo simil es precisamente la preposición EN :

"pasar mis manos por mi pecho enjuto, coger tus ples on peces que gotean."
} 
Algunos críticos han querido ver en estos poemas un extremado hermetismo y se han limitado a no comentarlos; no han querido, por razones incomprensibles, pensar por un momento el mundo por donde la poetisa anduvo, universo angustiado y donde toda relación conceptual era imposible; de lo extraño de ese mundo y de la imposibilidad comunicativa del lenguaje resulta el gran esfuerzo expresivo de la poesía. Este ha sido uno de los principales motivos que despertó nuestro interés y todas las sinuosidades de nuestra andanza se pueden justificar con facilidad.

\section{I - DESDE TANTA DISTANCIA}

En los dos primeros versos del poema "La Fuga", cuyo título ya es sugestivo, Gabriela Mistral tuvo el cuidado de colocarnos en primer plano la palabra sueño; esta palabra, evidentemente, puede tener muchos significados y nos conviene, por lo menos, descartar el sentido onírico de la misma y quedarnos con toda su carga poética, complejo expresivo de vivencias estéticas. Sin detenernos en ello, fácilmente se puede adivinar que esta palabra sirve, en posición de destaque, para desmaterializar el paisaje, desconcretizar la realidad paisajística para enveredarnos por los caminos de un mundo poético, donde todo nos es extraño, porque no poseemos el nombre de sus objetos.

"Madre mía, en el sueño

ando por paisajes cardenosos:

un monte negro que se contornea siempre, para alcanzar el otro monte,"

- La fuga. -

No son abundantes los objetivos en los poemas que nos preocupan, pero son ricos en sugerencias. Aquí encontramos dos, cardenosos y negro, ambos con función bien representativa: el primero nos sugiere, nos anticipa consecuencias de golpe, moradez de herida que se derrama sobre un paisaje violáceo. El segundo nos comunica en seguida la idea de laberinto, sombrío y oscuro. En todo caso los dos calificativos reflejan el estado de tristeza y vaguedad de la autora y, al mismo tiempo, subjetivizan el paisaje, desmaterializándolo, 
como hemos dicho. Hay en este primer poema un juego de ondulaciones, de bajadas y de subidas, como olas de un mar infinito, en un vaivén de oscuridades:

" $y$ en el que sigue estás tú vagamente, peno siempre hay otro monte redondo que circundar, para pagar el paso al monte de tu gozo y de mi gozo." - La fuga -

El adjetivo redondo y el verbo circundar nos dan prueba de ello. Estas ondulaciones van ganando lejanía hacia la meta inalcanzable; se pierden en un continuo e interminable entrecruce. Los dos encabalgamientos

\section{"pero siempre hay otro monte redondo que circundar, para pagar el paso al monte de tu gozo y de mi gozo."}

son expresivos, transfieren la ondulación del camino, el esfuerzo de la cuesta y del barranco, el cansancio y la lentitud del andar. Son encabalgamientos extensivos de movimiento: el primero es muy suave y el segundo es un esfuerzo de arranque, pues la contracción al es la antepuerta, la invitación a subir. Los verbos acompañan también el impulso hacia la subida.

Hasta aquí la poetisa nos ha puesto en contacto, por decirlo así, con el mundo por donde se mueve; después se convence de la imposibilidad del hallazgo definitivo y se hace pesimista, porque está cansada del caminar. Todo ha sido un conato de desdoblamiento y un engaño de enfoque. Ese mundo de ondulaciones, como camino hacia la madre, es ella misma, grande y desesperada como las criaturas de Dios:

"Y me das unas voces de sarcasmo desde tres puntos, $\mathrm{y}$ en dolor me rompo, porque mi cuerpo es uno, el que me diste,"

$$
\text { - La fuga - }
$$

Este primer poema es la guía de la obra; los otros siete son dilataciones: estado pesimista, duda ante la bondad di- 
vina $\mathrm{y}$, finalmente, consuelo en Cristo. Esta constante se refleja también en algunas imágenes:

"y hay que enhebrar los cerros repetidos,"

- La fuga -

"ensartados en un rayo de gloria"

- La fuga -

" $y$ he cantado cosiendo mis cerros

por cogerte en el grito los pies"

- Nocturno de la Derrota.

Estas tres imágenes procuran limitar las distancias, se'van haciendo más humanas y ganan definitivamente la unidad dolorida, círculo de corazón triste, como vereda hacia el encuentro divino:

"Acaba de llegar, Cristo, a mis brazos,"

- Nocturno del Descendimiento.

Un hilo de cariño, que por momentos se perdía en las ondulaciones de la ruta, la ha levantado con humildad y de todas las dispersiones ha hecho un rosario de esperanza:

"siempre por el rosario de los cerros;"

Todo ha sido un movimiento hacia la unidad, un recoger todas las dispersiones doloridas hasta hacerse dolor definitivo, como el Cristo del Calvario.

Todos los verbos de las imágenes citadas (enhebrar, ensartar, coser), son verbos del quehacer femenino, un quehacer $\tan$ femenino cuanto el instinto de maternidad, siempre presente en la obra de Gabriela Mistral(i).

La sintesis de la expresión se ha conseguido, en este caso, a través del valor metafórico de los verbos. Estas imágenes son de gran riqueza sugestiva y el proceso de construcción

(3) - Encontramos un verso con el título de varios poemas dedicados a los niños, poetras conocidos universalmente por la ternura y por la delicadeza de esta mujer que no fue madre:

"de las canctones de cuna

mecldo como de tallos," 
ha sido muy simple: todo ha consistido en colocarle a estos verbos transitivos un complemento ajeno a sus acciones habituales y normales: ("y hay que enhebrar los cerros repetidos"). En algunos casos este metaforismo de verbos le sirve a la poetisa para expresar intensamente su dolorido estado de angustia:

"Hace tanto que masco tinieblas, que la dicha no sé reaprender; tanto tiempo que piso las lavas que olvidaron vellones los pies; tantos años que muerdo el desierto..."

- Nocturno de la consumación.

Sin embargo hemos de considerar también el valor metafórico de tinieblas, desierto etc.,. Hay entre verbos y objetos, por tanto, una corriente de interpenetración, los dos elementos se ponen en contacto produciendo, en síntesis, una metáfora doble: masco tinieblas. La relación entre los dos planos se ha conseguido de una manera absurda, proceso característico de la poesía contemporánea; tal vez encontremos algo parecido en poetas anteriores, pero no con la misma intensidad y frecuencia.

Esta estrofa nos comunica el estado espiritual de la poetisa sin el auxilio de los adjetivos, tan comunes en poemas de tendencias subjetivistas. Lo absurdo del proceso metafórico enriquece de sugerencias estos versos y el acúmulo adjetival desaparece. Estos elementos formales encontraron su recompensa.

Los adjetivos no son muy abundantes, como vemos, pero nos comunican también la crisis de la poetisa ${ }^{(4)}+$ : país de los cerros cardenosos, largo desánimo religioso y esperanzada resignación. Todos los adjetivos reflejan ese mundo de la

(4) - La propla Gabriela nos expllca esta crisls: "Ella se me volvió una larga y sombría posada; se me hizo un país en que vivi cinco o slete afios, país amado a causa de la muerta, odioso a causa de la volteadura de mi alma en una larga crisis religiosa. No son ni buenos ni bellos los llamados "frutos del dolor" y a nadie se los deseo. De regreso de esta vida en Ia més prieta tinlebla, vuelvo a decir, como al final de DESOLACIÓN, la alabanza de la alegría. El tremendo viaje acaba en la esperanza de las "Locas Letanias" y cuenta su remate a quienes se culdan de $\mathrm{ml}$ alma y poco saben de mí desde que viro errante." - TALA - ob. clt. páglna 154. 
autora de manera enriquecedora y poética. Pero en un poema los adjetivos tienen función objetiva y real, es el instante en que Gabriela, ante el sepulcro materno, se mantiene bastante más serena y recuerda "visualmente" a su madre:

"parados ojos que me miraron con tal mirada que me ceñía; regazo ancho que calentó como una hornaza que no se enfria; mano pequeña que me tocaba con un contacto que me fundía..."

- Lápida filial -

Los verbos ceñir, calentar, enfriar y fundir transmiten a los substantivos la carga afectiva $\mathrm{y}$, por tanto, subjetiva; pero los adjetivos nos ponen en relieve concretamente a la madre de ojos parados, regazo ancho y manos pequeñas. En este momento la poetisa chilena está serena y la madre no se le ha confundido en la oscuridades de los paisajes cardenosos. Toda la afectividad subjetiva se ha conseguido precisamente con los verbos; los adjetivos, como vemos, realizan aquí otra función. En otros casos los calificativos anticipan cualidades y refuerzan así el valor expresivo de las imágenes que se van sucediendo; en estos casos son lindero entre lo real y lo puramente poético:

\footnotetext{
"Te olvidaste del rostro que hiciste en un valle a una oscura mujer; olvidaste entre todas tus formas mi alzadura de lento ciprés,"”
}

- Nocturno de la Consumación -

El adjetivo oscura tiene ya valor metafórico, es, aqui, un vocablo puramente poético y la imagen del cuarto verso se enriquece mucho por causa del adjetivo. Supongan la palabra mujer así, sola, genérica e indeterminada; todo esto no le comunicaría nada o casi nada a la imagen "mi alzadura de lento ciprés". El adjetivo ha formado con el nombre una unidad emocional más humana y ha derramado sobre el mismo esclarecimientos más hondos y comunicativos. Esta anticipación adjetival puede exigir el desplazamiento del vocablo lento. Desde luego todo ha sido conseguido a través de 
giros, de rodeos de construcción. La poesía, una vez más, resulta un enriquecimiento comunicativo.

La mayoría de las estrofas de este poema son reiteraciones del mismo contenido poético; los adjetivos que van surgiendo reiteran también el núcleo poético base que ya analizamos. La mujer es oscura y lenta, olvidada por Cristo; después es pobre mujer, cara rendida, leño triste, pez sombrio. Todos los calificativos con valor poético se refieren precisamente a ella, los otros son normales, como, por ejemplo, el hacer "cosas gloriosas" de Dios. La reiteración le va inyectando intensidad ${ }^{(5)}$ a todo este poema. Si por un lado hemos encontrado reiteración adjetival, conceptual o temática, vamos a encontrar también reiteraciones metafóricas correspondientes. Veamos estas dos metáforas cuyo plano real es el mismo:

$$
\begin{aligned}
& \text { leño triste (a) } \\
& \text { pez sombrio (b) }
\end{aligned}
$$

Las reiteraciones correspondientes son estas:

"Dame tú el acabar de la encina
en fogón que no deje la hez;" (a')
"dame el fin de la pobre medusa
que en la arena consuma su bien."

El problema no se encierra en el caso analizado, ni mucho menos; es un convite al estudio formal de la poesía de Gabriela Mistral. El estado de angustia continuada ha encontrado también un medio de prolongarse en la forma. Toda esta ramificación tiene su tronco único: la mujer. Ocupémonos, para terminar, de otro ejemplo:

"Ahora que ya no me acuerdo de nada,

El ímpetu del ruego que traía

se me sume en la boca pedigueña, de hallarme en este pobre anochecer con tu bulto vencido en una cuesta

(5) - Sobre esto véase: Bousono, Carlos: "Teoría de la exprestón poética" Biblloteca Románica Hispánica - Editorial Gredos - Madrid - 1956 2.2 ediclón. Páginas 120/123. 
que cae y cae y cae sin parar

en un trance que nadie me dijera.

Desde tu vertical cae tu carne

en cáscara de fruta que golpean:

el pecho cae y caen las rodillas

y en cogollo abatido, la cabeza".

- Nocturno del Descendimiento -

Un verso nos llama en seguida la atención porque en él se repite tres veces el mismo verbo (caer) y dos la conjunción $(y)$. El verso es muy expresivo(6) y requiere rápido comentario: caer es un verbo de movimiento y su significado supone una meta, un punto final y definitivo. La poetisa ha querido eliminar esa barrera última que concretiza toda caída y lo ha hecho magníficamente negándole el significado a otro verbo ${ }^{(7)}$, esto es, transformando el estatismo del verbo parar en movimiento. Este proceso poético se engrandece si llevamos en consideración que la "caída" se refiere a Cristo $\mathrm{y}$, que, por tanto, es infinita, como la autora nos deja bien claro. El movimiento de caer se prolonga sin limitación en este verso y el verbo reiterado en él nos anticipa, como en el caso de algunos adjetivos, una emoción poética que se repetirá más pormenorizada.

\footnotetext{
"Desde tu vertical cae tu carne en cáscara de fruta que golpean: el pecho cae $y$ caen las rodillas $y$ en cogollo abatido, la cabeza."
}

La reiteración del verbo caer y de la conjunción $y$ estira el movimiento, lo prolonga hasta el desmoronamiento total; este desmoronameinto total alcanza su sentido poético porque Gabriela Mistral nos anticipó sintéticamente el significado que ella quiso darle al verbo caer y al mismo tiempo por el hecho de haber colocado al final del último verso de la estro-

(6) - Dejamos de lado el estudio del símbolo, por razones ya dichas, pero queremos recordar que la stmbologia de estos poemas se aproxtma mucho a la de Antonio Machado, el poeta español de la Generación del 98. La poetisa brasileña Henriqueta Ltsboa se vale tamblén de una simbologia semejante. Véase, por ejemplo, "Velário".

(7) - Esta construcción no tiene nada de original, puesto que es común y de frecuento uso. Lo original está precisamente en la transcendencla que gana en el verso. 
fa la palabra cumbre: cabeza. El verbo se repite en estos versos tres veces y la conjunción dos; el número de las reiteraciones coincide con el número de los elementos repetidos en el verso ya analizado ("que cae y cae y cae sin parar"): hay una armonía matemática en la reiteración de la que nos ocupamos, un equilibrio muy significativo; si la "caída" se refiere al Ser divino, el desmoronamiento debe de ser equilibrado, harmoniosamente rítmico $\left(^{3}\right)$. Toda esta "caída" sin barrera final es el símbolo del sufrir divino por la humanidad, del venir hacia lo terreno, hacia el suelo de los hombres; es infinita, como nos dice la poetisa, porque los seres humanos la dejan pasar, por indiferencia o aridez de entrañas, no quieren hacerle freno o provocarle la parada. No se nos ocorre, como al Marcelino de la película infantil, quitarle a Cristo la corona de espinas y preguntarle por su dolor:

"y esta caída, los que son tus hijos, como no te la ven no la sujetan,"

- Nocturno del Descendimiento -

Toda la congoja particular de Gabriela Mistral se ha borrado ante el dolor de Cristo, porque una mujer es siempre un arco de brazos abiertos al dolor del mundo, un regazo maternal para el descanso:

"Acaba de llegar, Cristo, a mis brazos, peso divino, dolor que me entregan, ya que estoy sola en esta luz sesgada..."

- Nocturno del Descendimiento -

La obra de Gabriela Mistral es siempre el abrazo final y cariñoso de una mujer como ella.

São José do Rio Prêto, noviembre de 1961

Eduardo Peñuela Cañizal - Professor universitário.

(8) - Téngase presente que la poetisa esté ante un "Cristo artístico" en el monte del Calvario; el primer contacto con la "divindad se dio a través del arte de la estatua $y$ por una intulción estética y emocional, la poetisa capta "una verdad" tan humana y al mismo tiempo tan divina, que el contenido, el mensaje, gana hondura. No podemos detenernos en este complejo intuitivo $\mathrm{y}$ artistico, recomendamos al lector las expllcaciones de: Heldegger, Marttn: "Arte y Poesia" - Traducción y prologo de Samuel Ramos - Fondo de Cultura Económica - México - 1958 - página 56 en adelante. 